wind, but M. Plantamour thinlks it is likely to be fine weather, and on this recommendation I took a place in the diligence for Chamounix. . . .

"Chamounix, Sept. I $8,185 \mathrm{r}$.- Last evening the stars were shining through the opening clouds, giving promise of improving weather, but a glance out of the window this morning dispels all such anticipations. . . .

"Chamounix, Sept. I9, 1851.-I woke this morning at five, and my first impulse was to go to the window to see the signs of the weather. Last night 1 had hopes of an improvement. But I was surprised to find a clear sky ; some clouds were resting round the aiguille, but the summit of Mont Blanc was clear. Started for Montanvert at 7.15 with a guide. ...

"Mcr de Glace.- . . . Attempted two or three times to hide the sun's disc by projecting rocks to try to see the red prominences, but could not get a station far enough off. ...

"Chamounix, Sept. 20, 1851.-Snowing fast in morning. Weather desperately bad. But before going to bed it was quite clear.

"Chamounix, Sept. 2x, 1851.- . . The fine prospects of last night were effectually put aside by another snowstorm. ...

Chamounix, Sept. 22, 1851.-The morning bad as usual. ...

Chamounix, Sept. 23, I851.-This morning still cloudy, yet the prospect for an improvement was encouraging. Soon after breakfast the sun appeared struggling in the clouds, and I hurried off with a spy-glass not to lose the slightest chance of seeing the phenomena I wished to. ... I spent two or three hours in the wet fields to no purpose. In the afternoon there was an effort at clearing again.

"Chamounix to Martigny, Sept. 24, 1851.-The clouds this morning still hung on the mountains, but overhead there seemed some signs of clear sky. To make sure of losing no chance I took an early breakfast and left for the fields with the ordinary spy-glass belonging to the hotel under my arm. Sometimes it would be almost clear, and then again it began to rain, and I was undecided whether to give up and start for Martigny or to stay another day. At last I saw the sun's disc and took up my station on the edge of the shadow of the Aiguille de Blettière. It was still cloudy, but I was satisfied from the nature of the experiment-

"Ist. That a very clear air is necessary.

"2nd. Plenty of time to choose projections, affording views of as large a portion of the circumference of the disc as possible while the rest is hidder.

"And lastly, a good achromatic telescope easily moved.

"I did not expect to find it so easy an experiment, nor to find a mass so well fitted for the purpose as the Aiguille. de Blettière, which has a smooth edge, inclined, so as to allow the sun to disappear slowly behind it,

"The naked eye easily bears a small portion of the sunlight. From 7 to $9 \frac{1}{2} \mathrm{I}$ followed the shadow over the valley. It was nearly clear for a few moments before it reached the woods on the side of the mountain, but there were still some light clouds over the sun, and nothing could be seen certainly of the corona; the clouds and mist would account for what I did see, and on the other hand the colour of the telescope supplied too much red just at the edge for one to be able to see any of the red flames, if they existed there.

"On the whole, I am more than ever sure that the experiment can be made, and I think will be by some one more fortunate than I."

\section{SOLAR OBSERVATION IN INDIA}

NOW that the subject of solar observation in India is likely to occupy the attention of the scientific public he following details of the Solar Observatory now in pro- gress of construction at Calcutta may be of interest to readers of NATURE.

The suggestion emanated in the first place from the well-known Italian astronomer and spectroscopist, Prof. Tacchini, who was sent to India by the Italian Govern. ment as director of the Transit of Venus Expedition. The idea thus put forth was at once taken up by Père Lafont, the principal of St. Xavier's College. A subscription was opened to enable the work to be carried on, and in a short time the collections had amounted to 10,000 rupees, to which the Indian Government added 5,000 rupees. So warmly does the idea seem to have been taken up, that a theatrical benefit was given, at the suggestion of Col. Wyndham, in aid of the Observatory fund.

The observations proposed to be carried out are to supplement those made in Italy, where from November to March (inclusive) the sky is often unfavourable for observation. A complete annual record of changes in the sun's chromosphere, \&c., will thus be kept up. With regard to instruments, an equatorial of 7 -inch aperture is now being constructed by Merz, but more funds are needed to complete the instrumental "plant" of the Observatory. In course of time it is to be hoped that a transit instrument and a complete set of meteorological apparatus will be added.

The Italian Transit of Venus Expedition has thus been the means of sowing seeds which, finding themselves in a soil most favourable for development, are calculated at no very distant period to bear fruit of the greatest value to science. When in Calcutta with the Royal Society's Eclipse Expedition, last April, I visited the Observatory in company with Prof. Tacchini, and the work of construction was then in a very advanced state. Prof. Tacchini has recently written to say that the building is now almost completed.

The energy which has been displayed in connection with the Calcutta Observatory * redounds greatly to the credit of our Indian colleagues. It is only by systematic observations of this kind, carried on by public enterprise, that we can ever hope to detect cyclical changes in the sun's composition and constitution-changes which, taking enormous periods for their completion, may demand continuous records to be carried on even through many generations.

R. MELDOLA

\section{THE LAWS OF STORMS†}

M FAYE, in the article referred to below, and of which we propose to give an abstract at considerable length, begins by referring to the stupendous force of tropical tempests as contrasted with those of Europe, and to the practical importance of knowing the laws which regulate them. Many persons, he believes, on reading the title of his paper, will be surprised to learn that hurricanes have laws, or will ask what an author means by proposing to expound and vindicate the Law of Storms.

Laws of Storms.--Not only are storms subject to laws of great interest to science, but from these laws practical rules may be deduced which will enable us to avoid these dangers, or escape from them, should we happen to be caught in a storm. These rules are taught in all naval schools, and are the foundation of the sailor's safety. The validity of the laws on which they are based has, however, been disputed by some writers on Meteorology, and therefore the Bureau des Longitudes has authorised the publication of M. Faye's paper, in which he attempts clearly to expound and to defend the disputed laws.

Referring to the valuable labours of Piddington in India and Redfield in the United States, and of Reid, M. Faye says that the only premises they had to start * The Observatory is situated in St. Xavier's College, Park Street, Calcutta.

$\dagger$ Abstract of a paper, "Défense de la Loi des Tempêtes, par M. Faye, Membre de l'Institut," in the Anxurire of the Bureau des Longitudes fo $I^{8} 75$. 